DOI: $10.1038 /$ s41467-018-04643-5 OPEN

\title{
Author Correction: Structural analysis of human ARS2 as a platform for co-transcriptional RNA sorting
}

\author{
Wiebke Manuela Schulze ${ }^{1}$, Frank Stein ${ }^{2}$, Mandy Rettel ${ }^{2}$, Max Nanao $^{1,3}$ \& Stephen Cusack (D) ${ }^{1}$
}

Correction to: Nature Communications https://doi.org/10.1038/s41467-018-04142-7, published online 27 April 2018

The previously published version of this Article contained an error in Fig. 1. In panel d, the Arabidopsis SERRATE protein was incorrectly labelled 'Human SERRATE' and should have been labelled 'SERRATE'. The error has been corrected in both the PDF and HTML versions of the Article.

Published online: 31 May 2018

\begin{abstract}
(c) (i) Open Access This article is licensed under a Creative Commons Attribution 4.0 International License, which permits use, sharing, adaptation, distribution and reproduction in any medium or format, as long as you give appropriate credit to the original author(s) and the source, provide a link to the Creative Commons license, and indicate if changes were made. The images or other third party material in this article are included in the article's Creative Commons license, unless indicated otherwise in a credit line to the material. If material is not included in the article's Creative Commons license and your intended use is not permitted by statutory regulation or exceeds the permitted use, you will need to obtain permission directly from the copyright holder. To view a copy of this license, visit http://creativecommons.org/licenses/by/4.0/.
\end{abstract}

(C) The Author(s) 2018

\footnotetext{
${ }^{1}$ European Molecular Biology Laboratory, Grenoble Outstation, 71 Avenue des Martyrs, CS 90181, Grenoble Cedex 9 38042, France. ${ }^{2}$ European Molecular Biology Laboratory, Heidelberg, Meyerhofstraße 1, Heidelberg 69117, Germany. ${ }^{3}$ Present address: ESRF-The European Synchrotron, Avenue des Martyrs 71, CS40220, Grenoble Cedex 9 38043, France. The original article can be found online at https://doi.org/10.1038/s41467-018-04142-7. Correspondence and requests for materials should be addressed to S.C. (email: cusack@embl.fr)
} 